\title{
Cells per Milliliter
}

National Cancer Institute

\section{Source}

National Cancer Institute. Cells per Milliliter. NCI Thesaurus. Code C74919.

A unit of cell concentration expressed in cells per unit of volume equal to one milliliter. 